\section{Automobile Radiator Antifreeze and Windshield Washer Fluid as IBA Carriers for Rooting Woody Cuttings}

\author{
Calvin Chong ${ }^{1}$ and Bob Hamersma ${ }^{2}$ \\ Ontario Ministry of Agriculture, Food and RuralAffairs, Horticultural Research \\ Institute of Ontario, Vineland Station, Ont. LOR 2E0, Canada
}

Additional index words. ornamentals, propagation, nursery, cuttings, methanol, ethylene glycol, indolebutyric acid

\begin{abstract}
Terminal stem cuttings of four evergreens [arborvitae (Thuja occidentalis L.), 'Calgary Carpet' juniper (Juniperus sabina L.), 'Hetzii' juniper (Juniperus virginiana L.), and Tamarix juniper (Juniperus sabina L.)] and four deciduous \{Amur maple (Acer ginnala Maxim.), common lilac (Syringa vulgaris L.), ninebark [Physocarpus opulifolius (L.) Maxim.], and viburnum (Viburnum farreri Stearn)\} woody landscape shrubs were treated with $0 \%, 0.1 \%, 0.3 \%$, or $0.8 \%$ IBA mixed in talc or with $0 \%, 0.25 \%, 0.5 \%, 1.0 \%$, or $1.5 \%$ IBA dissolved in $95 \%$ ethanol, radiator antifreeze (95\% ethylene glycol), or windshield washer fluid (47.5\% methanol). None of the carriers were phytotoxic to the cuttings. Cuttings treated with IBA in radiator antifreeze or windshield washer fluid produced rooting in most taxa similar to those treated with IBA in ethanol. Cuttings of the evergreen taxa produced more roots with liquid than with talc IBA at similar concentration ranges. There were some differences in rooting performance (expressed in terms of percent rooting, mean root count per rooted cutting, and length of the longest root per cutting) of taxa to solvents and IBA concentrations. However, such differences, if any, were generally small or commercially insignificant, except for ninebark, which rooted optimally with no IBA and exhibited a large reduction in percent rooting with increasing IBA concentrations in windshield washer fluid. Chemical name used: indolebutyric acid (IBA).
\end{abstract}

Nursery propagators often enhance rooting of cuttings with IBA dispensed in powder (talc) or liquid formulations. Liquid preparations are easier to formulate and are more readily available in a wider range of concentrations (Berry, 1984; Bonamino and Blazich, 1984). Liquid IBA may also induce better rooting than talc IBA (Bonamino and Blazich, $1984)$ and, at high concentrations ( $\geq 1 \%$ IBA), may stimulate rooting of many difficult-toroot species (Chong and Daigenault, 1986).

Ethyl and isopropyl alcohols are the most commonly used solvents for dissolving the free acid of IBA and other auxins (Dirr and Heuser, 1987), although polyethylene glycol (Carbowax) has also been used (Dirr, 1981). Research by Barnes (1988) and Chong et al. (1992) demonstrated that other glycol-based (ethylene and propylene) products served effectively as IBA carriers. Similar root-promoting effects were obtained with a wide variety of landscape shrubs and tree taxa cuttings treated with IBA at concentrations up to $2 \%$ dissolved in ethanol or plumbing anti-

Received for publication 16 May 1994. Accepted for publication 29 Nov. 1994. We acknowledge the contribution of plant material by Willowbrook Nurseries, Fenwick, Ont., and Mori Nurseries and Niagara-Holland Nurseries, Niagara-On-The-Lake, Ont. The cost of publishing this paper was defrayed in part by the payment of page charges. Under postal regulations, this paper therefore must be hereby marked advertisement solely to indicate this fact.

${ }^{1}$ Research Scientist.

${ }^{2}$ Agricultural Technician. freeze-derived propylene glycol (Chong et al., 1992).

The research by Barnes (1988) and Chong et al. (1992) was restricted to selected glycolbased antifreezes, and there are other commercial products that could be just as useful. Before any nontraditional solvents can be used widely by nursery propagators, its efficacy must be demonstrated. The objectives of this study were to 1) evaluate car radiator antifreeze (glycol-based) and windshield washer fluid (methanol-based) as alternative IBA carriers; and 2) measure their effect on rooting cuttings from selected shrub taxa compared with traditional ethanol and talc carriers.

\section{Materials and Methods}

Terminal stem cuttings ( 10 to $12 \mathrm{~cm}$ long) were rooted from four evergreen and four deciduous woody landscape shrubs. The evergreens [rooting period (days)] were arborvitae (74), 'Calgary Carpet' juniper (80), 'Hetzii' juniper (70), and Tamarix juniper (73). The deciduous species were Amur maple (42), common lilac (63), ninebark (32), and viburnum (29).

The basal $1 \mathrm{~cm}$ of cuttings was dipped into pure talc or Stim-Root 1, 2, or 3 (Plant Products, Bramalea, Ont.; 0.1\%, $0.3 \%$, or $0.8 \%$ IBA in talc, respectively) or quick-dipped (5 sec) in $0 \%, 0.25 \%, 0.5 \%, 1.0 \%$, or $1.5 \%$ IBA dissolved in $95 \%$ laboratory-grade ethanol, Turbo Power car radiator antifreeze [95\% ethylene glycol plus small (unspecified) amounts tives; Rechochem, Montreal, Que.] or Turbo of antioxidants and other rust-inhibiting addi-
Power $-40 \mathrm{C}$ windshield washer fluid [47.5\% methanol plus small (unspecified) amounts of detergents and dyes]. The highest concentration of IBA $(1.5 \%)$ in radiator antifreeze or windshield washer fluid was dissolved with gentle stirring over low heat provided by a hot plate due to difficulty in dissolving this amount of IBA at room temperature.

Evergreen cuttings (last-season's growth) were taken in late Dec. 1991 from healthy commercial stock plants, placed in plastic bags, and stored for 2 weeks in a room held at 1 to 2 C. On 4 or 7 Jan. 1992, cuttings were trimmed to length, treated as described above, and inserted and rooted in a 3 perlite : 2 peat $(\mathrm{v} / \mathrm{v})$ medium in double-layer, polyethylenecovered greenhouse compartments with a $16 \mathrm{C}$ day/10C night cycle, $80 \%$ relative humidity, and $21 \pm 2$ C bottom heat (Chong et al., 1992). Deciduous cuttings (current-season's growth) were taken on 12 July, kept overnight at 1 to $2 \mathrm{C}$, then stuck in $100 \%$ perlite medium under lath (50\% shade) in outdoor frames and intermittent mist (Chong et al., 1992). Cuttings of each taxon were arranged in a separate randomized complete-block design with four replications and 25 cuttings per plot. Percent rooting of cuttings with one or more roots longer than $1 \mathrm{~mm}$, number of roots per rooted cutting, and length of the longest root per cutting were measured (evergreen, 8-21 Mar.; deciduous, 11-24 Sept.).

Data were analyzed separately by taxon. Transformations of the data were carried out but were unnecessary. Thus, each nontransformed rooting response was regressed on percent IBA by carrier, using a previously described regression model (Chong et al., 1991, 1992). Graphically, the model represents a series of curves, one for each carrier, radiating from a common intercept or from separate intercepts when significantly different. Quadratic polynomials were fitted when necessary to account for a curved relationship. When any two regressions of different liquid carriers were not significantly different at $P \leq 0.05$, a common regression was fitted for the two carriers. A similar procedure was followed when regressions for the three or four carriers were not significantly different. The coefficient of determination for each set of responses was expressed in terms of partial $r^{2}\left(\mathrm{p} r^{2}\right)$, which measured the strength of the response relationship after removing replication effects (Deveau et al., 1987).

\section{Results}

Percent rooting. IBA concentration had no statistically significant effect on percent rooting of arborvitae, 'Calgary Carpet' juniper, and 'Hetzii' juniper $\left[\mathrm{Y}_{\mathrm{TERW}}=\right.$ nonsignificant (NS)] (Fig. 1). Percent rooting of Tamarix juniper was not affected by talc IBA treatments but decreased with increasing IBA concentrations $\left(\mathrm{Y}_{\mathrm{ERW}}\right)$ using ethanol $(\mathrm{E})$, radiator antifreeze $(\mathrm{R})$, and windshield washer fluid (W).

Percent rooting of the deciduous taxa was more variable than that of the evergreens treated with IBA (Fig. 1). With the deciduous taxa, 
rooting due to talc IBA was similar to (Amur maple, ninebark, and viburnum) or better than (lilac) with most liquid media at similar concentrations. Amur maple responded curvilinearly to increasing IBA concentrations. A common trend was observed for ethanol and windshield washer fluid ( $\mathrm{Y}_{\mathrm{EW}}$, solid line), with an optimum of $85 \%$ rooting at $0.6 \%$ IBA. A separate trend for radiator antifreeze $\left(\mathrm{Y}_{\mathrm{R}}\right.$, rectangular broken line) had an optimum of $92 \%$ rooting at $1 \%$ IBA. With lilac, there also was a common trend for ethanol and windshield washer fluid and a separate one for radiator antifreeze. Ninebark rooting decreased minimally (slope $-6.7 \%$ rooting per $1 \%$ IBA concentration) as IBA concentration increased in ethanol or radiator antifreeze ( $\mathrm{Y}_{\mathrm{ER}}$, solid line). However, with windshield washer fluid, there was a substantial reduction (slope $-34 \%$ rooting per $1 \%$ IBA concentration), possibly due to phytotoxicity of this solvent at the higher concentrations. Viburnum rooted equally well $(>94 \%)$ regardless of solvent or concentration of IBA in solution.

Root count. There was no difference in root count response due to talc without IBA or any of the solvents without IBA, except for Amur maple (solvent $>$ talc) (Fig. 2). Talc IBA treatments had no significant effect $(P \leq 0.05)$ on root count of most taxa.

Root counts of all taxa, except Amur maple, increased (linearly or curvilinearly) with increasing IBA concentration (Fig. 2). There was a common response curve for all three solvents $\left(\mathrm{Y}_{\mathrm{ERW}}\right)$ for each of the taxa, 'Hetzii' juniper, Tamarix juniper, and Amur maple. With ninebark, there was a common curve for radiator antifreeze and windshield washer fluid $\left(\mathrm{Y}_{\mathrm{RW}}\right.$, solid line; optimum of 7.8 roots at $0.8 \%$ IBA) and a separate one for ethanol $\left(\mathrm{Y}_{\mathrm{E}}\right.$, broken line; optimum of 11.8 roots at $1 \%$ IBA). All other taxa, except 'Calgary Carpet' juniper, $Y_{E W}<Y_{R}$, had a common response curve for ethanol and windshield washer fluid, differing slightly or moderately with that for radiator antifreeze, depending on taxa and IBA concentration: lilac, $Y_{\mathrm{EW}}>\mathrm{Y}_{\mathrm{R}}$; viburnum, $\mathrm{Y}_{\mathrm{EW}}>\mathrm{Y}_{\mathrm{R}}$, most concentrations; arborvitae, $\mathrm{Y}_{\mathrm{EW}}>\mathrm{Y}_{\mathrm{R}}$ at higher IBA concentrations.

Root length. While root lengths in the evergreens differed little or not at all with the three solvents or in response to increasing IBA solutions (data not shown), corresponding values in the deciduous taxa increased markedly (Amur maple, $\mathrm{Y}_{\mathrm{ERW}}=5.6+11.8 \mathrm{x}-4.8 \mathrm{x}^{2}$ ), increased very little (viburnum, radiator antifreeze only, $Y_{R}=3.0+0.8 x-0.3 x^{2}$ ), showed no response (lilac, $\mathrm{Y}_{\mathrm{ERW}}=\mathrm{NS}$ ), or decreased slightly (ninebark, $\mathrm{Y}_{\mathrm{ERW}}=3.6-1.3 \mathrm{x}$; viburnum, ethanol and windshield washer fluid, $\mathrm{Y}_{\mathrm{EW}}=3.0+1.2 \mathrm{x}-1.0 \mathrm{x}^{2}$ ) with increasing IBA concentrations.

\section{Discussion}

This study demonstrates that IBA dissolved in radiator antifreeze and windshield washer fluid produced rooting in most of the taxa similar to IBA in ethanol. In view of the chemical similarity of methanol and ethanol, the greater similarity in rooting stimulation by

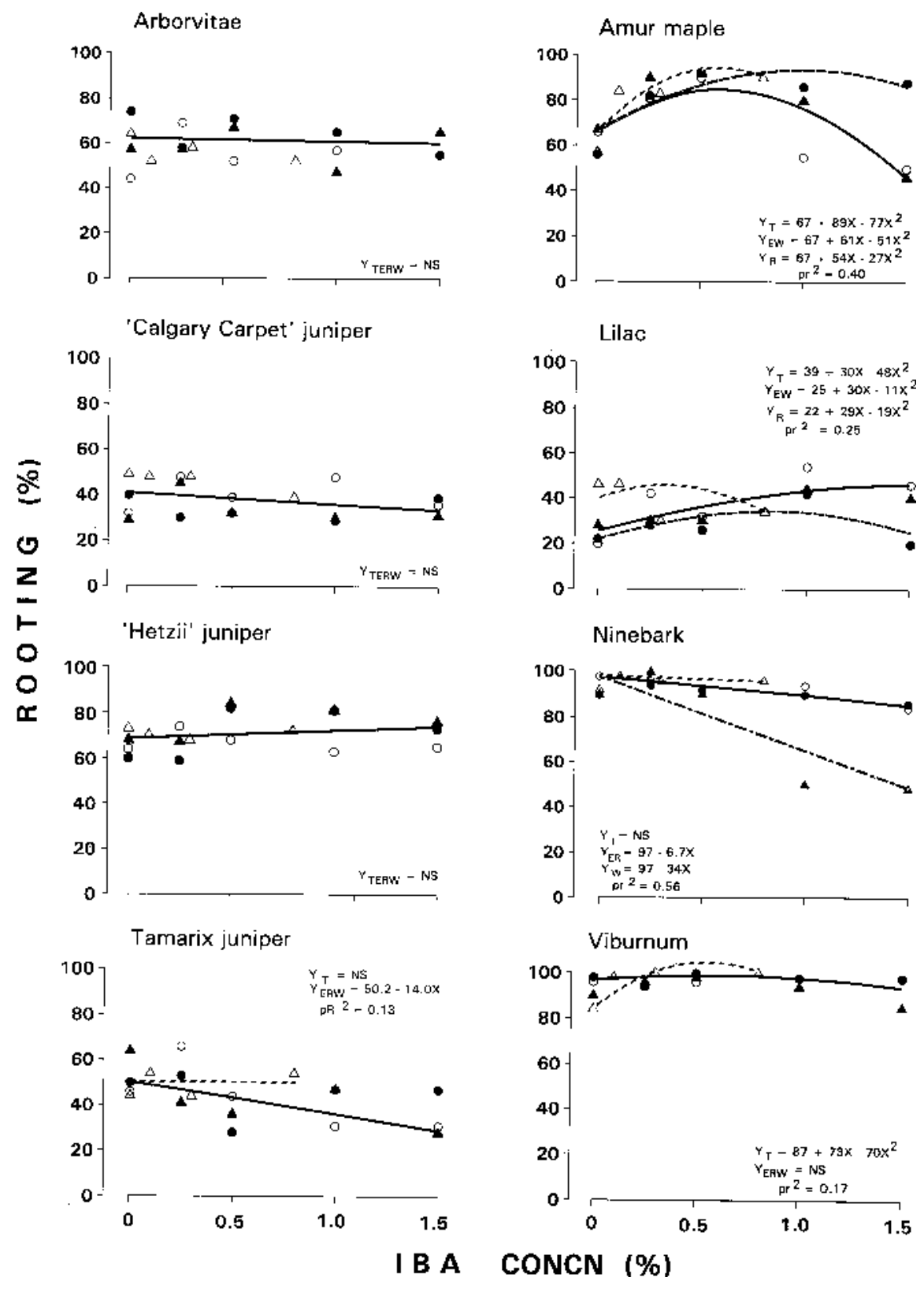

Fig. 1. Percent rooting of eight woody taxa in response to several carriers with various concentrations of IBA. The regression for each carrier is represented by $\mathrm{Y}_{\mathrm{T}}\left(\right.$ talc $\Delta$---- $\Delta$ ), $\mathrm{Y}_{\mathrm{E}}($ ethanol $\bigcirc----\bigcirc), \mathrm{Y}_{\mathrm{R}}$ (radiator antifreeze ---@), and $\mathrm{Y}_{\mathrm{W}}$ (windshield washer fluid $\boldsymbol{\Delta}---\boldsymbol{\Delta}$ ). $\mathrm{Y}_{\mathrm{ER}}, \mathrm{Y}_{\mathrm{EW}}, \mathrm{Y}_{\mathrm{ERW}}$, and $\mathrm{Y}_{\mathrm{TERW}}$ indicate nonsignificance among regressions at $P \leq 0.05$ for the two or more carriers represented in the subscripts, and are shown graphically as solid lines. Ns indicates that the slope, curvature, or both were nonsignificant at $P \leq 0.05 . \mathrm{p}^{2}$ represents the coefficient of determination after removing replication effects.

windshield washer fluid (methanol) and ethanol as carriers of IBA than between radiator antifreeze (ethylene glycol) and ethanol is not surprising. Cuttings of the evergreens produced more roots with liquid than with talc IBA at similar concentration ranges (Fig. 2). Similar to results of Chong et al. (1992), 1) none of the carriers per se caused any visible phytotoxicity; and 2) there was some IBAinduced basal necrosis in cuttings treated with the highest concentration of IBA $(1.5 \%)$, but the occurrence was similar with all three solvents.

Within each taxon, rooting differences, if any, due to solvents or IBA concentrations were generally small or commercially insignificant. Consequently, propagators can use any of the three solvents and expect similar results. The most notable exception to this observation was ninebark, which rooted optimally with no IBA and rooted much less with increasing concentrations of IBA in windshield washer fluid (Fig. 1).

This study provides additional information on the rooting of landscape shrub cuttings treated with IBA in nontraditional solvents. Car radiator antifreeze and windshield washer fluid are suitable solvents for IBA and are nonphytotoxic to woody cuttings. With IBA, both stimulated rooting generally as well as ethanol containing IBA. Being more readily available and less expensive than alcohols and other solvents and, perhaps also, recently tested propylene glycol (potable water system anti- 


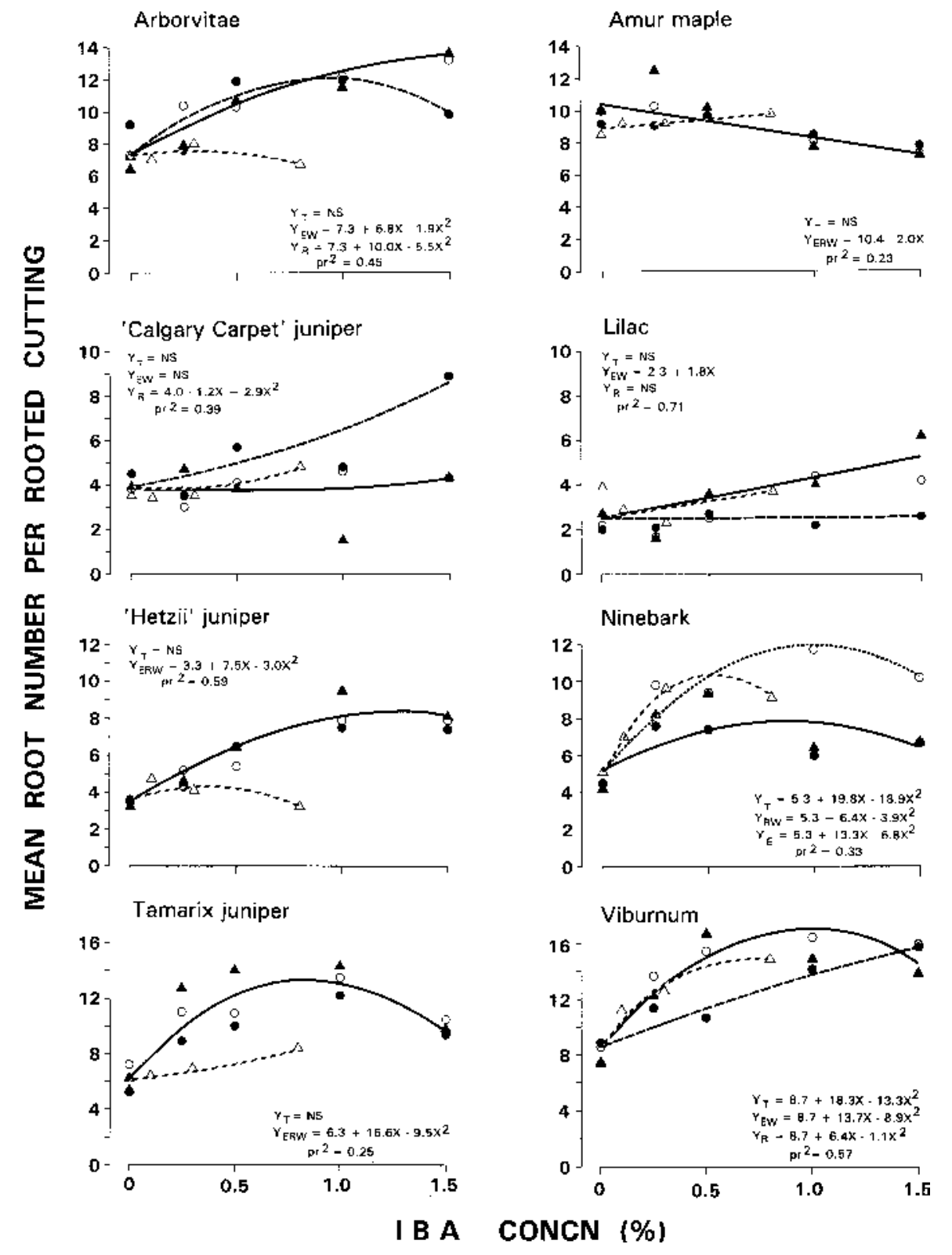

Fig. 2. Mean root number per rooted cutting of eight woody taxa in response to several carriers with various concentrations of IBA. The regression for each carrier is represented by $\mathrm{Y}_{\mathrm{T}}(\operatorname{talc} \Delta----\Delta), \mathrm{Y}_{\mathrm{E}}(\mathrm{ethanol} \bigcirc-$ ---O), $\mathrm{Y}_{\mathrm{R}}$ (radiator antifreeze----@), and $\mathrm{Y}_{\mathrm{W}}$ (windshield washer fluid $\left.\mathbf{\Delta}----\boldsymbol{\Delta}\right) . \mathrm{Y}_{\mathrm{EW}}, \mathrm{Y}_{\mathrm{ERW}}$, and $\mathrm{Y}_{\mathrm{TERW}}$ indicate nonsignificance among regressions at $P \leq 0.05$ for the two or more carriers represented in the subscripts, and are shown graphically as solid lines. Ns indicates that the slope, curvature, or both were nonsignificant at $P \leq 0.05 . \mathrm{p}^{2}$ represents the coefficient of determination after removing replication effects. freeze) (Chong et al., 1992), radiator antifreeze and windshield washer fluid have the potential to be more widely used by nursery propagators.

\section{Literature Cited}

Barnes, H.W. 1988. The use of glycols as solvents for rooting hormones. Comb. Proc. Intl. Plant Prop. Soc. 38:517-521.

Berry, J.B. 1984. Rooting hormone formulations: A chance for advancement. Comb. Proc. Intl. Plant Prop. Soc. 34:486-491.

Bonaminio, V.P. and F.A. Blazich. 1984. Can liquid indolebutyric acid produce better rooting than auxin-talc mixtures? Amer. Nurseryman 159(11):99-104

Chong, C., O.B. Allen, and H.W. Barnes. 1992. Comparative rooting of stem cuttings of selected woody landscape shrub and tree taxa to varying concentrations of IBA in talc, ethanol and glycol carriers. J. Environ. Hort. 10:245250.

Chong, C., R.A. Cline, D.L. Rinker, and O.B. Allen. 1991. Growth and mineral nutrient status of containerized woody species in media amended with spent mushroom compost. J. Amer. Soc. Hort. Sci. 116:242-247.

Chong, C. and L. Daigneault. 1986. Influence of IBA-concentrations on rooting of woody perennial nursery stock. Comb. Proc. Intl. Plant Prop. Soc. 36:108-115.

Deveau, J.L., D.P. Ormrod, O.B. Allen, and D.W. Beckerson. 1987. Growth and foliar injury responses to maize, soybean and tomato seedlings exposed to mixtures of ozone and sulphur dioxide. Agr. Ecosystems Environ. 19:223240.

Dirr, M.A. 1981. Rooting compounds and their use in plant propagation. Comb. Proc. Intl. Plant Prop. Soc. 31:472-479.

Dirr, M.A. and C.W. Heuser, Jr. 1987. The reference manual of woody plant propagation: From seed to tissue culture. Varsity Press, Athens, Ga. p. 239. 